\title{
Two new genera of Medeterinae (Diptera: Dolichopodidae) from Baltic amber and some new combinations
}

\author{
Ава новых рода подсемейства Medeterinae (Diptera: Dolichopodidae) \\ из балтийского янтаря и нескомько новых сочетаний
}

\author{
I.Ya. Grichanov ${ }^{1}$, O.P. Negrobov ${ }^{2}$, O.V. Selivanova ${ }^{2}$ \\ И.Я. Гричанов ${ }^{1}$, О.П. Негробов ${ }^{2}$ О.В. Секиванова ${ }^{2}$
}

\footnotetext{
${ }^{1}$ All-Russian Institute of Plant Protection, Podbelskiy roadway 3, St. Petersburg, Pushkin 196608, Russia. E-mail: grichanov@mail.ru

2 Department of Ecology and Systematics of Invertebrate Animals, Biological-Soil Sciences Faculty, Voronezh State University, Universitetskaya sq. 1, Voronezh 394006, Russia. E-mail: negrobov@list.ru

Всероссийский институт защиты растений, шоссе Подбельского 3, Санкт-Петербург-Пушкин 196608, Россия.

${ }^{2}$ Кафедра экологии и систематики беспозвоночных животных, биолого-почвенный факультет, Воронежский государственный университет, Университетская площадь 1, Воронеж 394006, Россия.
}

KEY WORDS: Diptera, Dolichopodidae, Systenites, Palaeosystenus, Palaeoargyra, Baltic amber, new genus, key. КЛЮЧЕВЫЕ СЛОВА: Diptera, Dolichopodidae, Systenites, Palaeosystenus, Palaeoargyra, балтийский янтарь, новый род, определитель.

ABSTRACT. Two new genera, Systenites gen.n. and Palaeosystenus gen.n. (Diptera: Dolichopodidae: Medeterinae) are described from Baltic amber. The new genera are similar to the extant genera of the subfamily Medeterinae, tribe Systenini, but differing in wing veins $\mathrm{R}_{4+5}$ and $\mathrm{M}_{1+2}$ straight and subparallel behind $d m-c u$; acrostichals uniseriate, equal in length; male $7^{\text {th }}$ abdominal segment reduced. The following recombinations are proposed: Systenites argutus (Meunier, 1907) (Porphyrops), comb.n., Systenites inclytus (Meunier, 1907) (Porphyrops), comb.n., Systenites splendidus (Meunier, 1907) (Xiphandrium), comb.n., Palaeosystenus succinorum (Meunier, 1907) (Porphyrops), comb.n., Palaeoargyra mutabilis (Meunier, 1907) (Argyra), comb.n. A key to extinct medeterine genera from Baltic amber is compiled, as well as a key to species of Medeterites Grichanov, 2010, Palaeosystenus and Systenites. Extant genera Argyra Macquart, 1834, Rhaphium Meigen, 1803 and Systenus Loew, 1857 and subfamily Rhaphiinae are excluded from the Baltic amber fauna. Palaeoargyra dytei Evenhuis, 1994 is placed in synonymy to P. mutabilis (Meunier, 1907), syn.n.

РЕЗЮМЕ. Описаны два новых рода из Балтийского янтаря: Systenites gen.n. и Palaeosystenus gen.n. (Diptera: Dolichopodidae: Medeterinae). Новые роды отличаются от современных родов трибы Systenini, в основном, следующими признаками: жилки крыла $\mathrm{R}_{4+5}$ и $\mathrm{M}_{1+2}$ прямые и параллельные; акростихальные щетинки однорядные, равные по длине; 7-й сегмент брюшка самцов редуцирован. Предложены новые родовые сочетания: Systenites argutus (Meunier, 1907) (Porphyrops), comb.n., Systenites inclytus (Meunier, 1907) (Porphyrops), comb.n., Systenites splendidus (Meunier, 1907) (Xiphandrium), comb. n., Palaeosystenus succinorum (Meunier, 1907) (Porphyrops), comb.n., Palaeoargyra mutabilis (Meunier, 1907) (Argyra), comb.n. Составлен определитель вымерших родов Medeterinae из Балтийского янтаря и определитель видов Medeterites Grichanov, 2010, Palaeosystenus и Systenites. Рецентные роды Argyra Macquart, 1834, Rhaphium Meigen, 1803 и Systenus Loew, 1857 и подсемейство Rhaphiinae исключены из фауны Балтийского янтаря. Вид Palaeoargyra dytei Evenhuis, 1994 сведён в синонимы к P. mutabilis (Meunier, 1907), syn.n.

\section{Introduction}

Until recently the subfamily Medeterinae was known from Baltic amber by only extant genera Medetera Fischer von Waldheim, 1819, Thrypticus Gerstaecker, 1864 and Systenus Loew, 1857 with poorly described extinct species [Meunier, 1907, 1908a, b; Evenhuis, 1994]. Grichanov [2010] erected a new medeterine genus Medeterites to include one extinct species Thrypticus molestus Meunier, 1907, supposed that "Chrysotus" decorus Meunier, 1907, is congeneric with $M$. molestus, and compiled a key to all dolichopodid genera from Baltic amber with apical aristalike stylus. Several pieces of Baltic amber are here studied with two medeterine species that can be placed into neither extant nor extinct genera and deserves new generic names. This paper offers a description of two new genera along with a key to extinct medeterine genera from Baltic amber. New combinations are proposed for some old species. As a result, extant genera 
Argyra Macquart, 1834, Rhaphium Meigen, 1803 and Systenus and subfamily Rhaphiinae are excluded from the Baltic amber fauna.

The specimens studied are housed at the collection of the Paleontological Institute of the Russian Academy of Sciences (PIN). They were studied and illustrated with ZEISS Discovery V-12 stereomicroscope and AxioCam MRc5 camera. Morphological terminology follows Cumming and Wood [2009] and Grichanov [2010]. The relative lengths of the antennomeres and podomeres should be regarded as representative ratios and not measurements. Body length is measured from the base of the antenna to the tip of abdominal segment 6. Antenna length is measured from the frons to the stylus apex. Wing length is measured from the base to the wing apex.

\section{Systematics}

\section{Systenites Grichanov, Negrobov et Selivanova, gen.n.}

TYPE SPECIES. Porphyrops inclyta Meunier, 1907: 209.

DESCRIPTION. This generic diagnosis is mainly based on males of type species studied, and lists features considered to be of generic importance.

Small species. Body generally dark, weakly shining; major bristles dark; vertex not excavated; upper occiput flat; vertical bristle strong and long, positioned at upper corner of frons; short postvertical seta as a linear continuation of postocular setal row; one pair of strong ocellar bristles with adjacent pair of hairs; single row of short simple postoculars of about equal length; eyes with microscopic hairs between facets; facets of equal size all over the eye; face under antenna 1.5 times as wide as postpedicel height, narrowing towards clypeus; facial suture indistinct; antenna distinctly longer than eye height; scape and pedicel small, simple; scape somewhat elongated, with at least 3 dorsal setae; pedicel globular, with circlet of apical setulae of approximately equal length; postpedicel much longer than high at base, shortly haired; arista-like stylus apical or strictly subapical, filiform, shortly pubescent, with its $1^{\text {st }}$ segment being very short and slightly thickened. Palpus as long as clypeus, ovate, with strong apical bristle; proboscis slightly projecting, with 6 pseudotracheae on each side.

Thorax: with posterior third of mesonotum distinctly flattened; 1 strong humeral, 1 sutural, 1 long and 1 short notopleurals, 2 strong supraalars, 1 long postalar bristle; 2 regular rows of 6 strong dorsocentrals decreasing in length anteriorly; the rows slightly diverging posteriorly; acrostichals in single regular row; 2 pairs of strong scutellars; postnotum distinct; 1 strong proepisternal seta just above fore coxa; proepimeron without strong setae.

Legs with usually short bristles, simple; fore coxa with short simple hairs and about 3 subapical setae anteriorly; mid and hind coxae with 1 strong lateral bristle at middle; claws and pulvilli on all legs small; mid trochanter with 1 dorsal seta; femora without strong setae; tibiae each with some apical setae; mid tibia with 2 pairs of strong antero- and posterodorsal bristles.

Wing: hyaline; $\mathrm{R}_{1}$ ending right before level of $d m-c u ; \mathrm{R}_{2+3}$ and $\mathrm{R}_{4+5}$ gradually diverging to wing apex, almost straight; $\mathrm{R}_{4+5}$ and $\mathrm{M}_{1+2}$ subparallel behind $d m-c u$. $\mathrm{M}_{1+2}$ almost straight, joining costa right behind wing apex. Crossvein $d m-c u$ slightly shorter than maximum distance between $\mathrm{R}_{4+5}$ and $\mathrm{M}_{1+2}$ veins. Anal vein distinct; anal lobe present; alula absent.

Abdomen: conoid, covered with hairs, with marginal tergal setae and sparse sternal hairs on segments 2-5; sterna 2-4 well sclerotised; tergum 6 very small; tergum 7 concealed; segment 8 large, positioned left basodorsally, covered with cilia, with 2 strong bristles (macrochaetae) posteriorly. Epandrium globular; apex of phallus simple, thick, pointed; surstylus broad, parallel-sided, with distal excavation, forming 2 apical teeth; cercus long and narrow.

DIAGNOSIS AND REMARKS. The following character states place Systenites in the Medeterinae [see Yang et al., 2006]:

Vertex not excavated; upper occiput distinctly flat; vertical seta nearly at level of oculus. Eyes with tiny hairs. Male eyes separated on face. Male face relatively narrow, narrowing downward. Postocular bristles one-rowed. Proboscis thick, projecting. Antennal stylus apical. Mesonotum with flat mid-posterior slope. Proepisternum not haired, only with separate bristle on mid-lower portion. Strong dorsocentrals decreasing in size anteriorly. Hairs on legs uniformly short. Hind coxa with 1 outer bristle at middle. Mid and hind femora without anterior preapical bristles. Anal cell absent; anal vein weak. Male abdominal segment 6 large triangular, with hairs and bristles. Male genitalia mostly exposed; surstylus strongly developed and distinctly divided.

The following character states distinguish Systenites from other Medeterinae:

Antennal scape somewhat elongated, with at least 3 dorsal setae (plesiomorphy); postpedicel much longer than high at base; arista-like stylus apical or strictly subapical, in male not longer than postpedicel; proboscis slightly projecting; wing with $\mathrm{R}_{1}$ long, ending right before level of $d m-c u$ (plesiomorphy); $\mathrm{R}_{4+5}$ and $\mathrm{M}_{1+2}$ straight and subparallel behind $d m$ $c u$ (plesiomorphy); $\mathrm{M}_{1+2}$ joining costa behind wing apex; male abdomen with tergum 6 very small; tergum 7 concealed; segment 8 large, with 2 strong bristles posteriorly; epandrium globular; cercus long and narrow; postgonite (?) is well visible between cerci, projecting.

The following character states distinguish Systenites from extinct medeterine genera (see also key below):

Wing veins $\mathrm{R}_{4+5}$ and $\mathrm{M}_{1+2}$ straight and subparallel behind $d m$-cu (symplesiomorphy); antennal scape somewhat elongated, with at least 3 dorsal setae (plesiomorphy); postpedicel much longer than high at base; arista-like stylus apical or strictly subapical, in male not longer than postpedicel; hind basitarsus about as long as next segment; epandrium globular; surstylus broad, parallel-sided, with distal excavation; cercus long and narrow, covered with long cilia, longest at apex.

The Systenites is certainly an ancestral systenin genus that can not be associated with any of the extant genera of the tribe. "Systenus" ciliatus Meunier, 1907 has most probably nothing to do with Systenus and extinct medeterine genera, as its postpedicel bears arista-like stylus inserted in apical notch of postpedicel, and its hind basitarsus is about half as long as next segment.

Included species (all from Baltic Amber):

Systenites argutus (Meunier, 1907), comb.n.

= Porphyrops arguta Meunier, 1907: 209.

= Argyra arguta (Meunier, 1907) [Evenhuis, 1994: 359].

Systenites splendidus (Meunier, 1907), comb.n.

= Xiphandrium splendidum Meunier, 1907: 209.

= Rhaphium splendidum (Meunier, 1907) [Evenhuis, 1994: 367]. 


\section{Systenites inclytus (Meunier, 1907), comb.n.} Figs 1-5.

Porphyrops inclyta Meunier, 1907: 209.

Argyra inclyta (Meunier, 1907) [Evenhuis, 1994: 359].

MATERIAL. Four almost completely preserved males in one piece of amber labelled: Baltic Amber, Upper Eocene - Lower Oligocene, no. 364/152 [PIN].

DESCRIPTION. Male. General coloration of head, thorax and abdomen brown-black, with metallic shine in certain light. Pollinosity is virtually indistinguishable. Major bristles dark.

Head: vertex not excavated; upper occiput flat; vertical bristle strong and long, positioned at upper corner of frons; short postvertical seta as a linear continuation of postocular setal row; one pair of strong ocellar bristles with adjacent pair of hairs; single row of short dark simple postoculars of about equal length; eyes with microscopic hairs between facets; upper and lower facets about equal in size; face light, matt, under antenna 1.5 times as wide as postpedicel height, narrowing towards clypeus; clypeus half as wide as face under antenna; facial suture indistinct; antenna distinctly longer than eye height, dark; scape and pedicel small, simple; scape somewhat elongated, with at least 3 dorsal setae; pedicel globular, with circlet of apical setulae of approximately equal length; postpedicel much longer than high at base (17/6), shortly haired; arista-like stylus apical or strictly subapical, filiform, shortly pubescent, with its $1^{\text {st }}$ segment being very
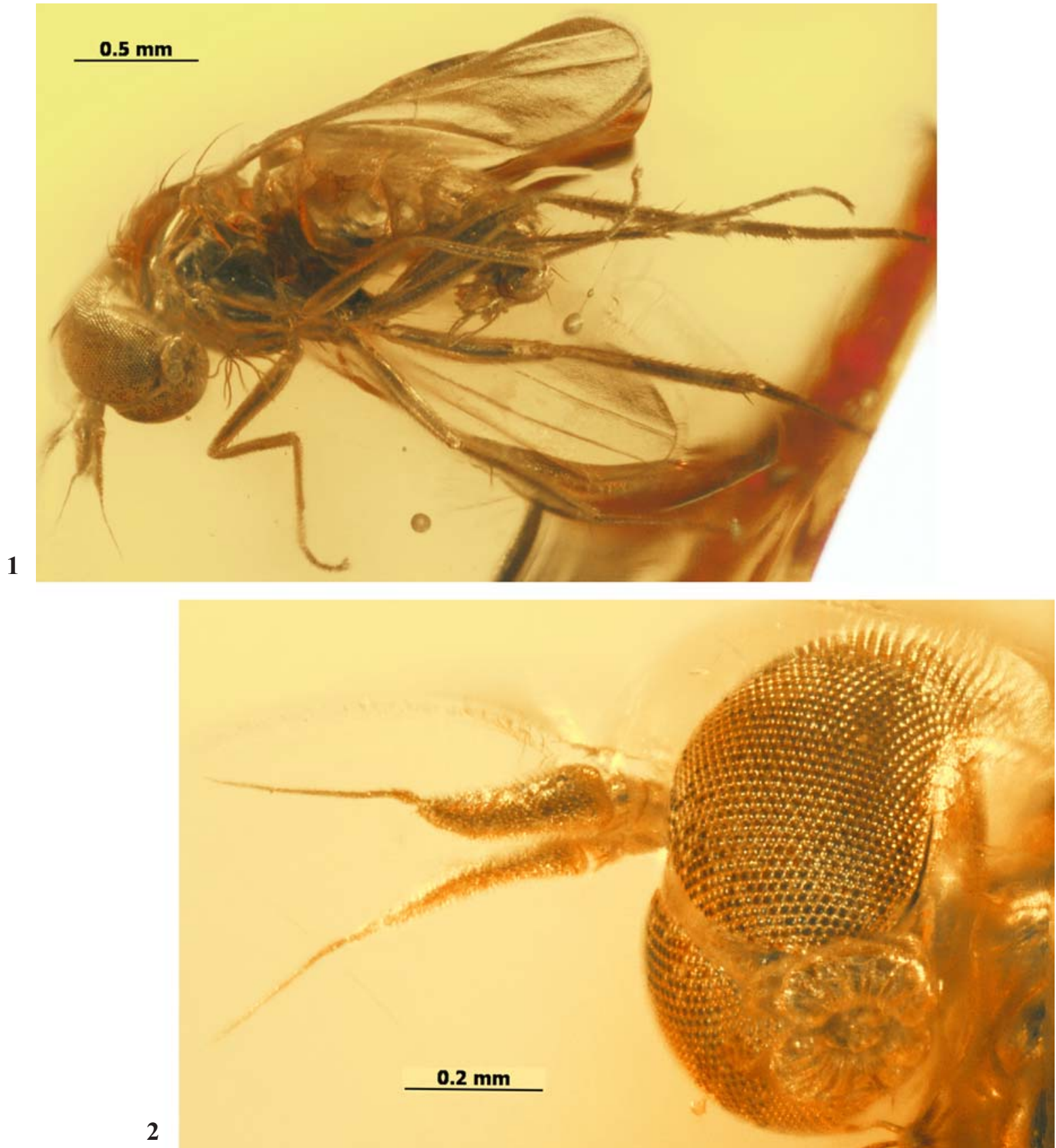

Figs 1-2. Systenites inclytus (Meunier): 1 - habitus; 2 - male head.

Рис. 1-2. Systenites inclytus (Meunier): 1 - внешний вид; 2 - голова самца. 
short and slightly thickened. Length ratio of scape to pedicel to postpedicel to arista-like stylus ( $1^{\text {st }}$ and $2^{\text {nd }}$ segments), $5 / 3$ / 17/2/15. Palpus and proboscis dark, small, sparsely haired; palpus as long as clypeus, ovate, with strong apical bristle; proboscis slightly projecting, with 6 pseudotracheae on each side.

Thorax: with posterior third of mesonotum distinctly flattened; 2 regular rows of 6 strong dorsocentrals decreasing in length anteriorly; the rows slightly diverging posteriorly; acrostichals in single regular row, distinct, reaching posterior depression of mesonotum; few hairs on anterior slope of mesonotum; 2 pairs of strong scutellars with lateral bristles shorter; postnotum distinct; 1 strong proepisternal seta just above fore coxa; proepimeron without strong setae.

Legs including coxae dark, simple, evenly covered with ordinary setulae, with usually short bristles (except for mid tibia); fore coxa with short simple hairs and about 3 subapical setae anteriorly; mid and hind coxae with 1 strong lateral bristle at middle; claws and pulvilli on all legs small; mid trochanter with 1 dorsal seta; femora without strong bristles, but all femora with 1 weak posteroventral subapical seta; fore tibia with 2 weak dorsals, with 3-4 apical setae; mid tibia with 2 pairs of strong antero- and posterodorsal bristles at $1 / 3$ and $2 /$ 3 , with 3-4 apicals; hind tibia with dorsal row of short setae, of which 3 setae reaching in length diameter of tibia, with 3-4 apical setae; tarsomeres of all legs with short apical setae; fore leg length ratio (from tibia to tarsomere 5): $38 / 20 / 10 / 7 / 5 / 5$, mid leg: 45/27/12/10/7/6, hind leg: 60/18/18/13/7/5.

Wing: hyaline, with brown veins; $\mathrm{R}_{1}$ ending right before level of $d m-c u ; \mathrm{R}_{2+3}$ and $\mathrm{R}_{4+5}$ gradually diverging to wing apex, almost straight; $\mathrm{R}_{4+5}$ and $\mathrm{M}_{1+2}$ subparallel behind $d m$ $c u$. $\mathrm{M}_{1+2}$ almost straight, joining costa right behind wing apex. Ratio of part of costa between $\mathrm{R}_{2+3}$ and $\mathrm{R}_{4+5}$ to this between $\mathrm{R}_{4+5}$ and $\mathrm{M}_{1+2}$ to $d m-c u$ to distal part of $\mathrm{CuA}_{1}, 40 / 30$ / $35 / 85$. Crossvein $d m-c u$ slightly convex, forming right angles with $\mathrm{CuA}$ and with $\mathrm{M}_{1+2}$ longitudinal veins, slightly shorter than maximum distance between $\mathrm{R}_{4+5}$ and $\mathrm{M}_{1+2}$ veins. Lower calypter light, with strong dark setae; halter light, with well developed rounded knob, as long as halter stem.

Abdomen: conoid, covered with hairs, with marginal tergal setae and sparse sternal hairs on segments 2-5; sterna $2-4$ well sclerotised; tergum 6 very small; tergum 7 con-

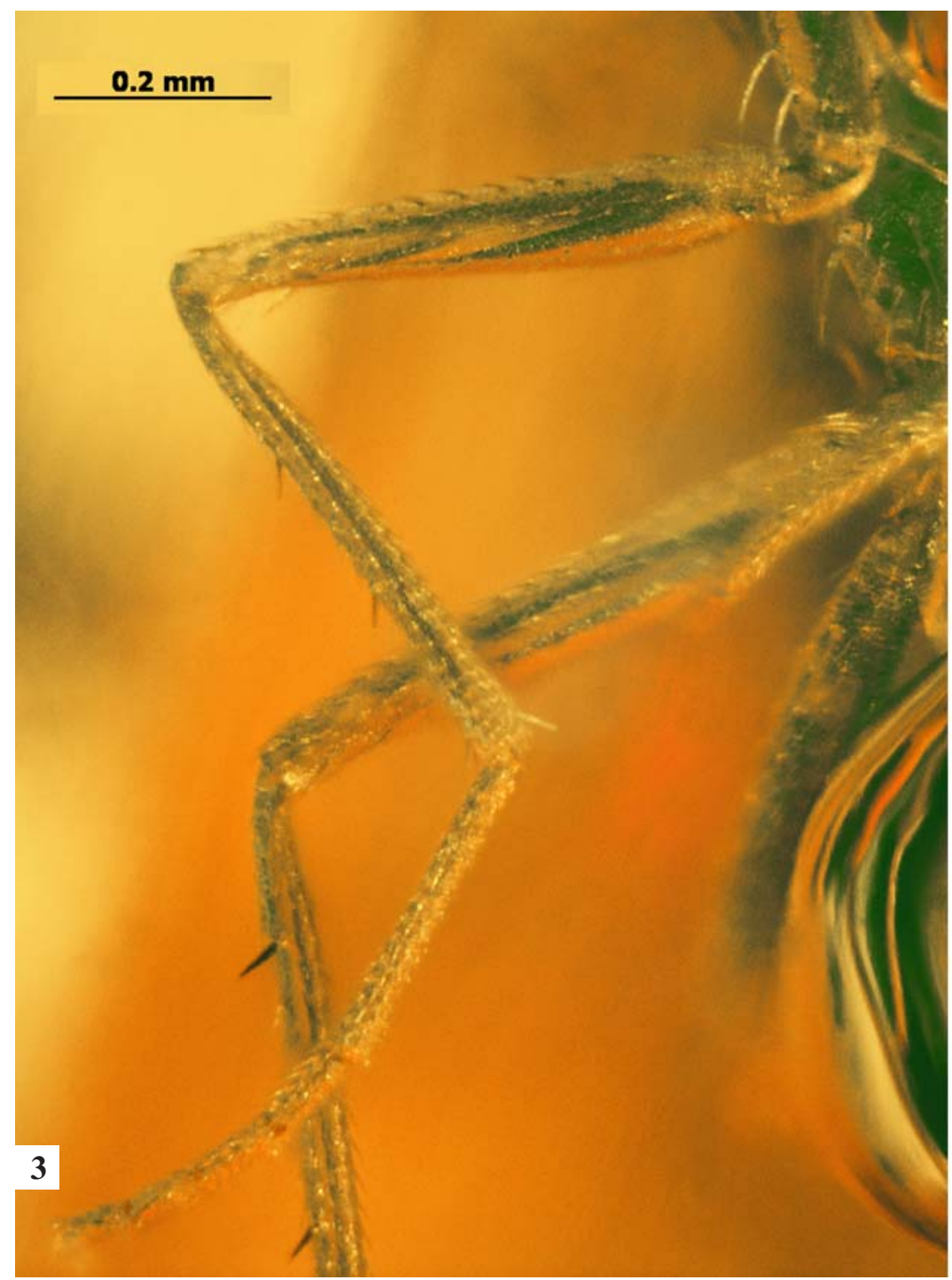

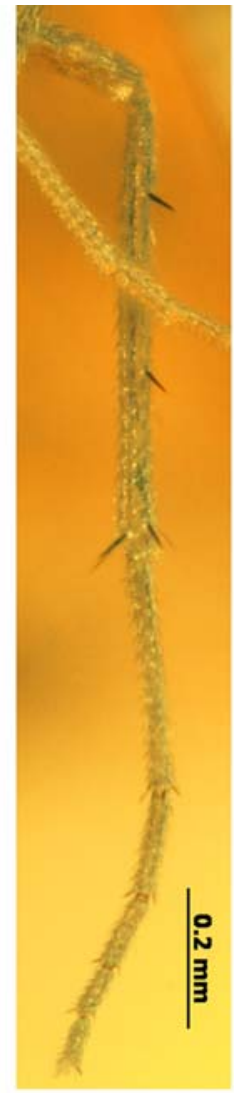

4

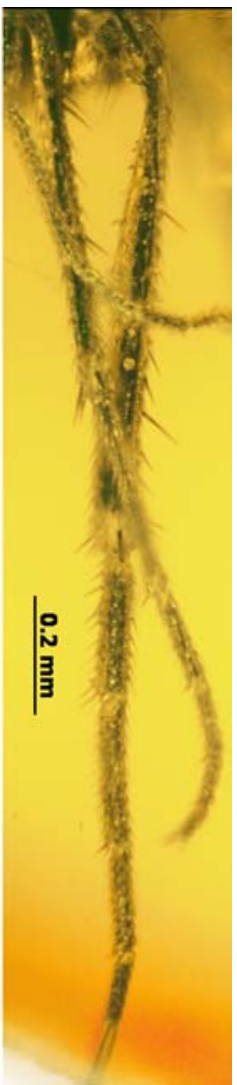

5

Figs 3-5. Systenites inclytus (Meunier): 3 - fore leg; 4 - mid leg; 5 - hind leg.

Pис. 3-5. Systenites inclytus (Meunier): 3 - передняя нога; $4-$ средняя нога; 5 - задняя нога. 
cealed; segment 8 large, positioned left basodorsally, covered with cilia, with 2 strong bristles (macrochaetae) posteriorly. Epandrium globular; hypandrium invisible; apex of phallus simple, thick, pointed; surstylus broad, $2 / 3$ cercal length, parallel-sided, with distal excavation, forming 2 apical teeth, of which ventral tooth bearing short apical spine; cercus long and narrow, nearly 1.5 times longer than epandrium, covered with long cilia, longest at apex; postgonite (?) is well visible between cerci, projecting, cleft in distal half, with 2 ovate lobes reaching first third of cerci.

Length $(\mathrm{mm})$ : body without antennae $2.1-2.2$, antenna 0.65 , wing $2.2 / 0.8$, hypopygium 0.5 .

Female [after Meunier, 1908b]. Postpedicel conoid, not longer or slightly longer than high at base; arista-like stylus about 2 times longer than postpedicel; body length $2.5 \mathrm{~mm}$, wing length $2.0 \mathrm{~mm}$.

DIAGNOSIS AND REMARKS. Systenites inclytus was originally described with the body length $1.75 \mathrm{~mm}$ in male and $2.5 \mathrm{~mm}$ in female; otherwise, the specimens examined have no principal differences from the description and pictures provided by Meunier. S. splendidus described by a male is apparently congeneric with $S$. inclytus, as it was described and figured with wing veins $\mathrm{R}_{4+5}$ and $\mathrm{M}_{1+2}$ straight and subparallel behind $d m-c u$; postpedicel much longer than high at base; arista-like stylus apical or strictly subapical, in male shorter than postpedicel; hind tibia setose dorsally; hind basitarsus about as long as next segment; epandrium globular; surstylus broad, parallel-sided, with distal excavation;

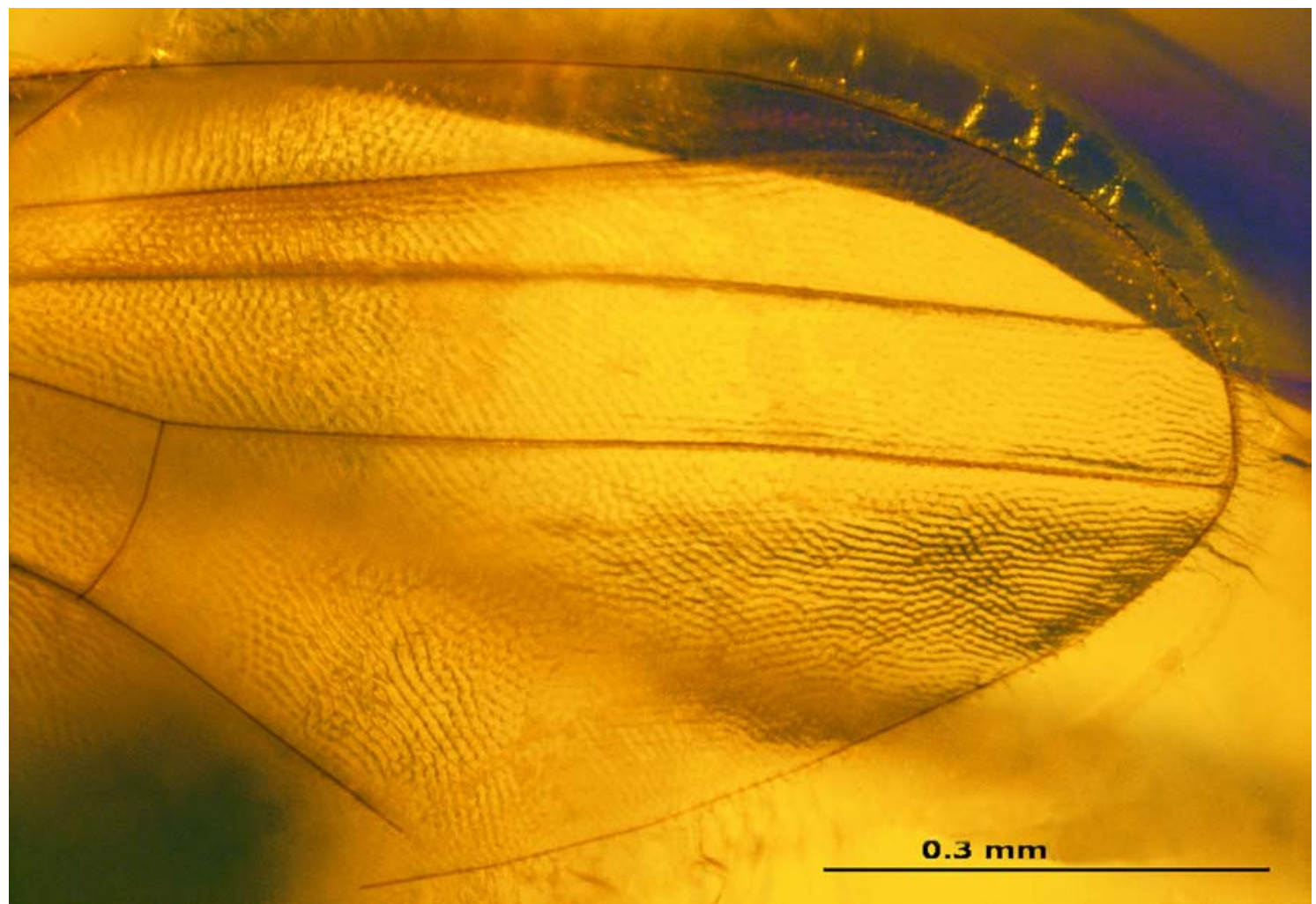

7

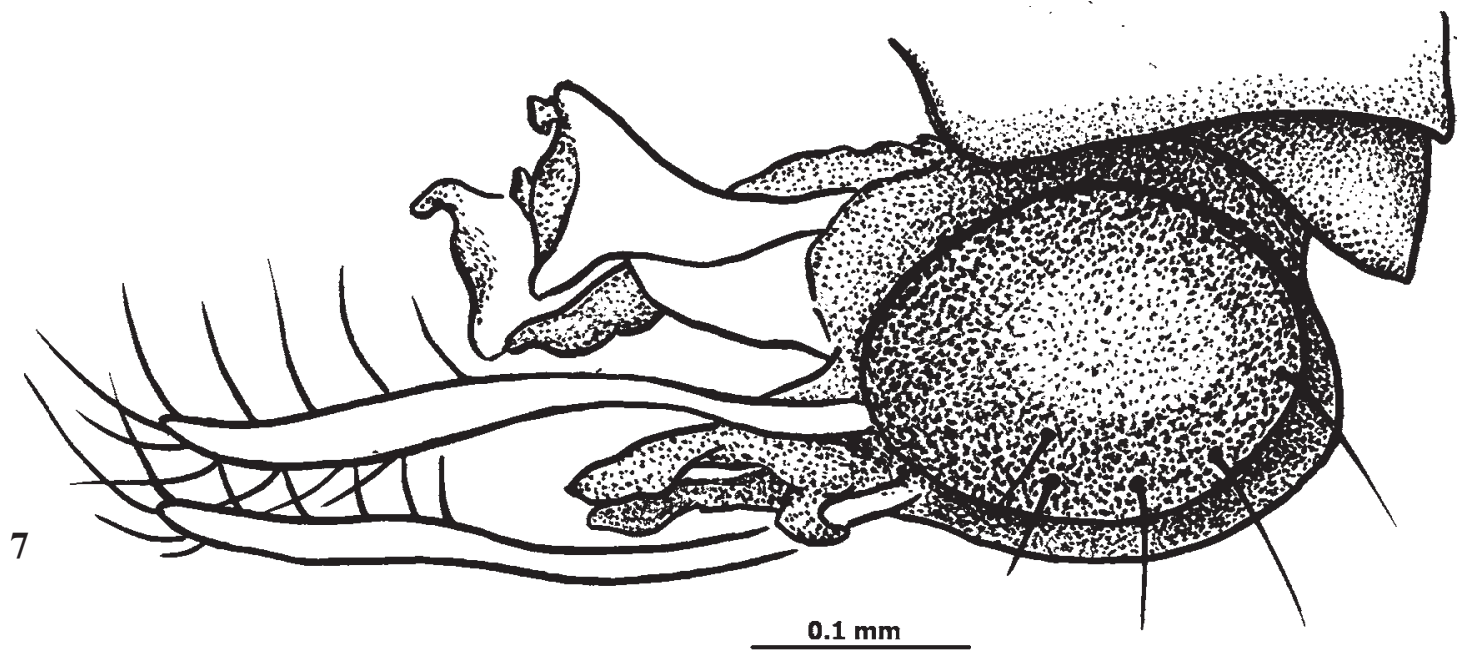

Figs 6-7. Systenites inclytus (Meunier): 6 - wing; 7 - hypopygium.

Рис. 6-7. Systenites inclytus (Meunier): 6 - крыло; 7 - гипопигий. 
cercus long and narrow, covered with long cilia, longest at apex. S. splendidus males differ from $S$. inclytus in arista-like stylus being about half as long as postpedicel and surstylus nearly reaching cercal apex. $S$. argutus was described by a female having such diagnostic for Systenites characters as setose scape [see Meunier, 1908b: Fig. 15], conoid postpedicel, parallel $\mathrm{R}_{4+5}$ and $\mathrm{M}_{1+2}$ veins, subequal first two segments of hind tarsus. $S$. argutus and $S$. inclytus females differ in length ratio of postpedicel and stylus (see key below).

\section{Palaeosystenus Grichanov, Negrobov et Selivanova, gen.n.}

TYPE SPECIES. Porphyrops succinorum Meunier, 1907: 209.

DESCRIPTION. This generic diagnosis is based on males of type species studied, and lists features considered to be of generic importance.

Small species. Body generally dark, weakly shining; major bristles dark; vertex not excavated; upper occiput flat; vertical bristle strong and long, positioned at upper corner of frons; short postvertical seta as a linear continuation of postocular setal row; one pair of strong ocellar bristles with adjacent pair of hairs; single row of short simple postoculars of about equal length; eyes with microscopic hairs between facets; facets of equal size all over the eye; face under antenna nearly 2 times as wide as postpedicel height, slightly narrowing towards clypeus; clypeus broad, nearly as high as wide; facial suture distinct; antenna about as long as eye height; scape and pedicel small, simple; scape glabrous; pedicel globular, with circlet of apical setulae of approximately equal length; postpedicel swollen at base, with drawn-out apex, much longer than high at base, shortly haired; arista-like stylus apical, filiform, shortly pubescent, with its $1^{\text {st }}$ segment being very short. Palpus as long as clypeus, ovate, with strong apical bristle; proboscis distinctly projecting.

Thorax: with posterior third of mesonotum distinctly flattened; 1 strong humeral, 1 sutural, 1 long and 1 short notopleurals, 2 strong supraalars, 1 long postalar bristle; 2 regular rows of 5 strong dorsocentrals decreasing in length anteriorly; the rows slightly diverging posteriorly; acrostichals in single regular row; 1 pair of strong scutellars; postnotum distinct; 1 strong proepisternal seta just above fore coxa; proepimeron without strong setae.

Legs with usually short bristles, simple; fore coxa with short simple hairs and about 3 subapical setae anteriorly; mid and hind coxae with 1 strong lateral bristle at middle; claws and pulvilli on all legs small; mid trochanter with 1 dorsal seta; femora without strong setae; tibiae each with some apical setae, otherwise practically devoid of distinct setae.

Wing: hyaline; $\mathrm{R}_{1}$ ending right before level of $d m-c u ; \mathrm{R}_{2+3}$ and $\mathrm{R}_{4+5}$ gradually diverging to wing apex, almost straight; $\mathrm{R}_{4+5}^{2+3}$ and $\mathrm{M}_{1+2}^{4+5}$ subparallel behind $d m-c u$, slightly convex anteriorly. $\mathrm{M}_{1+2}$ joining costa right behind wing apex. Crossvein $\mathrm{dm}-\mathrm{cu}$ slightly shorter than maximum distance between $\mathrm{R}_{4+5}$ and $\mathrm{M}_{1+2}$ veins. Anal vein distinct; anal lobe present; alula absent.

Abdomen: conoid, covered with hairs, with marginal tergal setae and sparse sternal hairs on segments $2-5$; sterna 2-4 well sclerotised; tergum 6 very small; tergum 7 concealed; segment 8 positioned left basodorsally, covered with cilia. Epandrium globular; apex of phallus simple, thick; surstylus bilobate, with ventral lobe longer; cercus very small, rounded-ovate.

DIAGNOSIS AND REMARKS. Palaeosystenus like Systenites and Medeterites has generally the character states that place the genus in the Medeterinae [see Yang et al., 2006].

The following character states distinguish Palaeosystenus from Systenites:
Antennal scape glabrous; postpedicel swollen at base, with drawn-out apex; arista-like stylus strictly apical; facial suture distinct; proboscis distinctly projecting; 5 strong dorsocentrals; $\mathrm{R}_{4+5}$ and $\mathrm{M}_{1+2}$ behind $d m$ - $c u$ slightly convex anteriorly; male segment 8 without strong bristles posteriorly; surstylus bilobate, with ventral lobe longer; male cercus very small, rounded-ovate.

The following character states distinguish Palaeosystenus from Medeterites:

Antennal postpedicel much longer, than high at base, swollen at base, with drawn-out apex; antenna sexually dimorphic; high; arista-like stylus shorter than postpedicel in male, about 2 times longer than postpedicel in female; 5 strong dorsocentrals; $\mathrm{R}_{4+5}$ and $\mathrm{M}_{1+2}$ behind $d m-c u$ slightly convex anteriorly; hind basitarsus slightly but distinctly shorter than next segment; male cercus very small.

The Palaeosystenus is probably closer to Systenites than to Medeterites.

Only one species from Baltic Amber is included: Palaeosystenus succinorum (Meunier, 1907).

\section{Palaeosystenus succinorum (Meunier, 1907), comb.n.}

Figs 8-13.

= Porphyrops succinorum Meunier, 1907: 209

= Argyra succinorum (Meunier, 1907) [Evenhuis, 1994: 359].

MATERIAL. Three completely preserved males partly covered with milky-white decay coating in two pieces of amber labelled: Baltic Amber, Upper Eocene - Lower Oligocene, nos. 364/242 and $364 / 350$; one completely preserved male and one partly destroyed female (?) in a piece of amber with the same label, no. 364/87; two partly destroyed males in two pieces of amber with the same label, nos. $364 / 88$ and $364 / 204$; one partly destroyed female in a piece of amber with the same label, no. 364/206 (PIN).

DESCRIPTION. Male. General coloration of head, thorax and abdomen dark, weakly shining. Pollinosity is virtually indistinguishable. Major bristles dark.

Head: vertex not excavated; upper occiput flat; vertical bristle strong and long, positioned at upper corner of frons; short postvertical seta as a linear continuation of postocular setal row; one pair of strong ocellar bristles (adjacent hairs invisible); single row of short dark simple postoculars of about equal length; eyes with microscopic hairs between facets; upper and lower facets about equal in size; face shining, under antenna nearly 2 times as wide as postpedicel height, slightly narrowing towards clypeus; clypeus broad, nearly as high as wide; facial suture distinct; antenna about as long as eye height, dark; scape and pedicel small, simple; scape vaselike, glabrous; pedicel globular, with circlet of apical setulae of approximately equal length; postpedicel swollen at base, with drawn-out apex, much longer than high at base (15/6), shortly haired; arista-like stylus apical, filiform, shortly pubescent, with its $1^{\text {st }}$ segment being very short. Length ratio of scape to pedicel to postpedicel to arista-like stylus, 4/4/16/12. Palpus and proboscis dark, small, sparsely haired; palpus as long as clypeus, ovate, with strong apical bristle; proboscis distinctly projecting.

Thorax: with posterior third of mesonotum distinctly flattened; 2 regular rows of 5 strong dorsocentrals decreasing in length anteriorly; acrostichals in single regular row, distinct, reaching posterior depression of mesonotum; few hairs on anterior slope of mesonotum; 1 pair of strong scutellars; postnotum distinct; 1 strong proepisternal seta just above fore coxa; proepimeron without strong setae.

Legs including coxae dark, simple, evenly covered with ordinary setulae, with usually short bristles; fore coxa with short simple hairs and about 3 subapical setae anteriorly; mid and hind 
coxae with 1 strong lateral bristle at middle; claws and pulvilli on all legs small; mid trochanter with 1 dorsal seta; femora without strong bristles, but all femora with 1 weak posteroventral subapical seta; fore tibia with at most 1 weak dorsal, with 2-3 short apical setae; mid tibia with at most 1 weak dorsal, with 2-3 short apicals; hind tibia without distinct setae, with 3-4 apical setae; tarsomeres of all legs with very short apical setae; fore leg length ratio (from tibia to tarsomere 5): 35/12/8/6/4/4, mid leg: 42/18/ 10/6/5/5, hind leg: 52/10/15/9/5/5.

Wing: hyaline, with brown veins; $\mathrm{R}_{1}$ ending right before level of $d m-c u ; \mathrm{R}_{2+3}$ and $\mathrm{R}_{4+5}$ gradually diverging to wing apex, $\mathrm{R}_{2+3}$ almost straight; $\mathrm{R}_{4+5}$ and $\mathrm{M}_{1+2}$ subparallel, slightly diverging behind $\mathrm{dm}$-cu, slightly convex anteriorly. $\mathrm{M}_{1+2}$ joining costa right behind wing apex. Ratio of part of costa between $\mathrm{R}_{2+3}$ and $\mathrm{R}_{4+5}$ to this between $\mathrm{R}_{4+5}$ and $\mathrm{M}_{1+2}$ to $d m$ - $c u$ to distal part of $\mathrm{CuA}$, $16 / 11 / 9 / 18$. Crossvein $d m-c u$ nearly straight, forming right angles with $\mathrm{CuA}_{1}$ and with $\mathrm{M}_{1+2}$ longitudinal veins, slightly shorter than maximum distance between $\mathrm{R}_{4+5}$ and $\mathrm{M}_{1+2}$ veins. Lower calypter light, with dark setae; halter light, with well developed rounded knob, slightly longer than halter stem.

Abdomen: conoid, covered with hairs, with short marginal tergal setae and sparse sternal hairs on segments $2-5$; sterna $2-$ 4 well sclerotised; tergum 6 very small; tergum 7 concealed; segment 8 positioned left basodorsally, covered with cilia.

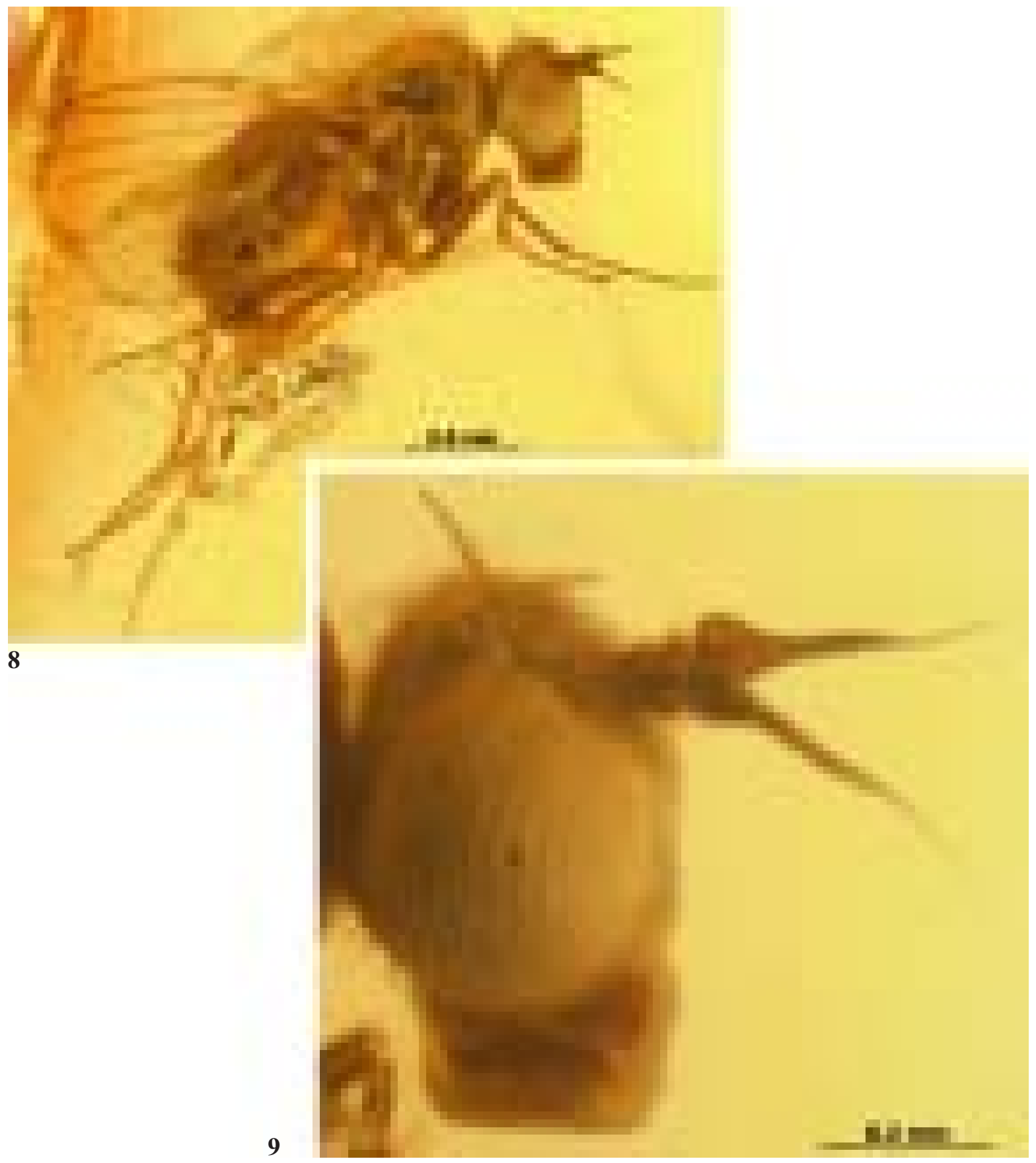

Figs 8-9. Palaeosystenus succinorum (Meunier): 8 - habitus; 9 - male head.

Рис. 8-9. Palaeosystenus succinorum (Meunier): 9 - внешний вид; 9 - голова самца. 


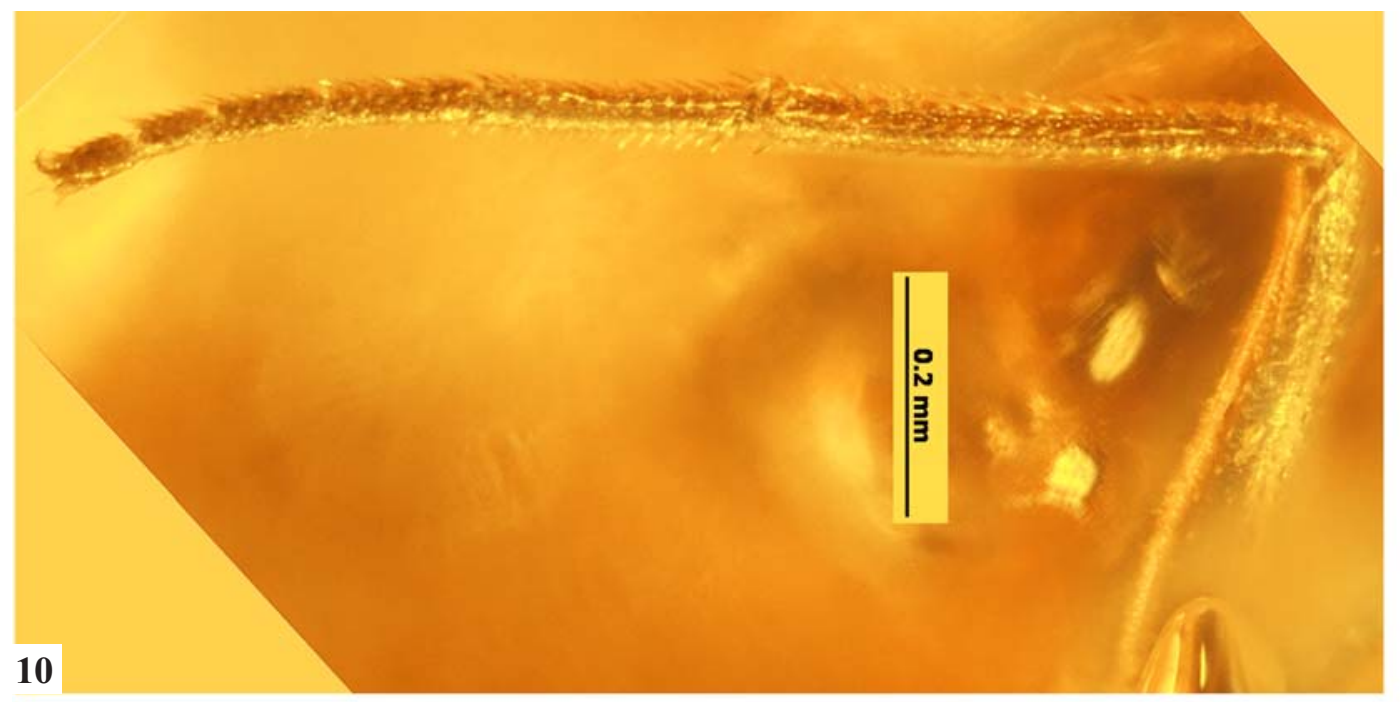

11

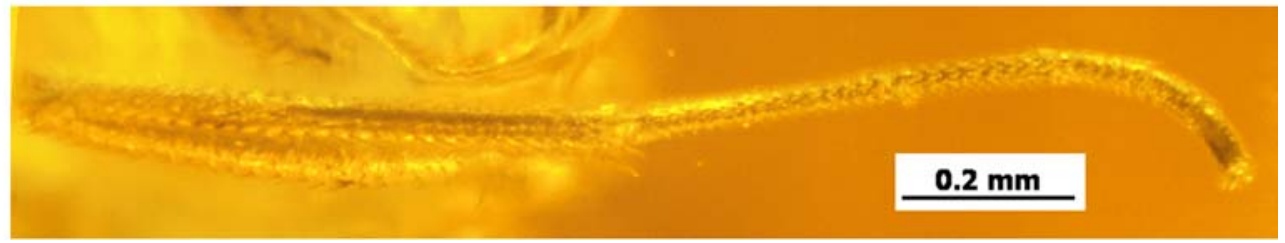

Figs 10-11. Palaeosystenus succinorum (Meunier): 10 - fore leg; 11 - mid leg.

Pис.10-11. Palaeosystenus succinorum (Meunier): 10 - передняя нога; 11 - средняя нога.

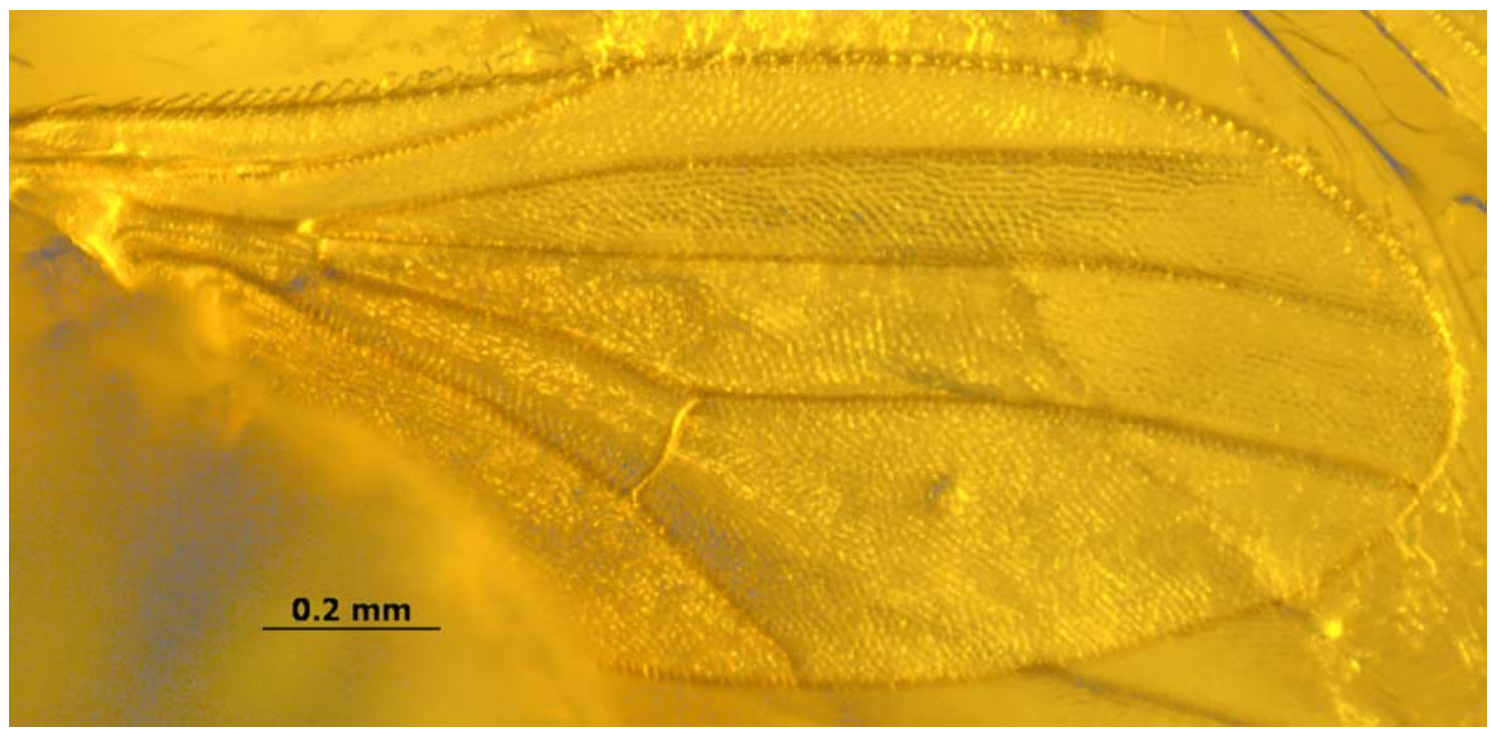

12

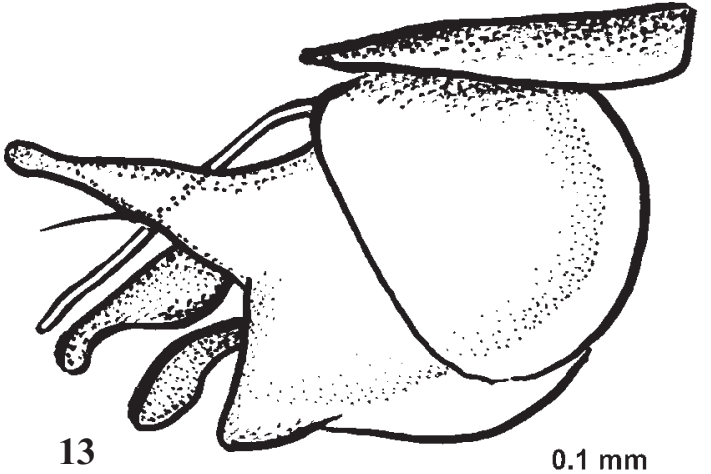

Figs 12-13. Palaeosystenus succinorum (Meunier): 12 - wing; 13 - hypopygium.

Рис. 12-13. Palaeosystenus succinorum (Meunier): 12 — крыло; 13 - гипопигий. 
Epandrium globular; hypandrium small; apex of phallus simple, thick; short distoventral epandrial lobe with strong apical bristle; surstylus (?asymmetrical) bilobate, with ventral lobe narrow, swollen at apex, half as long as epandrium, bearing short apical bristle; dorsal lobe of surstylus short, pointed; cercus very small, rounded-ovate, covered with short cilia.

Length $(\mathrm{mm})$ : body without antennae 1.8-2.0, antenna 0.45 , wing 1.7 , hypopygium 0.35 .

Female [after Meunier, 1908b]. Postpedicel conoid, with pointed apex, about 2 times longer than high at base; aristalike stylus about 2 times longer than postpedicel; body length $1.75 \mathrm{~mm}$, wing length $1.5 \mathrm{~mm}$.

KEY TO EXTINCT MEDETERINE GENERA FROM BALTIC AMBER AND EXTANT MEDETERINE TRIBES

1. Antennal postpedicel distinctly longer, sometimes much longer, than high at base, with acute or pointed apex in both sexes; antenna sexually dimorphic; usually 6 strong dorsocentrals.

- Antennal postpedicel not longer than high, usually rounded or subtriangular; antenna usually similar in male and female; usually 5 or fewer dorsocentrals.

2. $\mathrm{M}_{1+2}$ with flexion at middle of distal sector; $\mathrm{R}_{4+5}$ and $\mathrm{M}_{1+2}$ usually subapically bowed; acrostichals biseriate; posterior pair of acrostichals distinctly larger than preceding pair and offset laterally; male $7^{\text {th }}$ abdominal segment with tergite and sternite distinct. ................ extant Systenini

- Wing veins $\mathrm{R}_{4+5}$ and $\mathrm{M}_{1+2}$ straight and subparallel behind $d m-c u$; acrostichals uniseriate, equal in length; male $7^{\text {th }}$ abdominal segment reduced.

3. Antennal scape with at least 3 dorsal setae; postpedicel regularly narrowed towards pointed apex; male cercus long and narrow. ................................ Systenites gen. n.

- Antennal scape glabrous; postpedicel swollen at base, with drawn-out apex; male cercus short ... Palaeosystenus gen. $\mathbf{n}$.

4. Wing veins $R_{4+5}$ and $M_{1+2}$ straight and subparallel behind $d m-c u$; 6 strong dorsocentrals; acrostichals absent; male abdominal segment 7 short, not longer than tergum 6; epandrium globular; cercus big, rounded, covered with short cilia. ............................... Medeterites Grichanov

- $\mathrm{R}_{4+5}$ and $\mathrm{M}_{1+2}$ subparallel or convergent with $\mathrm{M}$ usually arched anteriorly; acrostichals aligned in two rows, rarely absent; usually 5 or fewer dorsocentrals; male abdominal segment 7 usually forming peduncle; epandrium elongate; cercus complicated.

extant Medeterini and Thrypticini

Key to species of Medeterites, PaLAEosystenus And SysTENITES

1. Antennal postpedicel not longer than high, rounded; acrostichals absent; hind basitarsus about half as long as next segment. ............. Medeterites molestus (Meunier)

- Antennal postpedicel distinctly longer, sometimes much longer, than high at base, with acute or pointed apex in both sexes; acrostichals present; hind basitarsus about as long as or shorter than next segment........................... 2

2. Antennal scape glabrous; postpedicel swollen at base, with drawn-out apex; male cercus shorter than epandrium; hind basitarsus shorter than next segment. Antennal scape with at least 3 dorsal setae; postpedicel regularly narrowing toward pointed apex; male cercus long and narrow, longer than epandrium; hind basitarsus about as long as next segment (Systenites). ............... 3

3. Arista-like stylus much longer than postpedicel (우) 4 - Arista-like stylus not longer than postpedicel $\left(\sigma^{7} \sigma^{7}\right) .5$
4. Arista-like stylus about 3 times longer than postpedicel. S. argutus

- Arista-like stylus about 2 times longer than postpedicel. S. inclytus

5. Arista-like stylus about half as long as postpedicel; surstylus nearly reaching cercal apex. ............. S. splendidus

- Arista-like stylus about as long as postpedicel; surstylus about half as long as cercus........................... S. inclytus

\section{Palaeoargyra Meunier, 1895}

= Palaeoargyra Meunier, 1895: 5 (subgenus of Argyra Macquart, 1834); Meunier, 1899: 179 (genus).

TYPE SPECIES. Palaeoargyra dytei Evenhuis, 1994 (designated by Evenhuis, 1994: 365; = Argyra mutabilis Meunier, 1907).

One species from Baltic Amber is included: Palaeoargyra mutabilis (Meunier, 1907), comb.n.

\section{Palaeoargyra mutabilis (Meunier, 1907), comb.n.}

= Argyra mutabilis Meunier, 1907: 210; Meunier, 1908: 16, 73-74, Figs 118-119.

= Palaeoargyra dytei Evenhuis, 1994: 365, syn.n.

DIAGNOSIS. Small species; body covered with distinct silvery pruinosity; antennal postpedicel conical, broad and quite obtuse at apex [after Meunier, 1895]; postpedicel conical, with stylus located ahead of its middle; male cercus filiform [after Meunier, 1908: 16]; body length $2 \mathrm{~mm}$; male stylus middorsal; scape bare; hind basitarsus slightly shorter than next segment; male cercus filiform, ciliated [after Meunier, 1908: 74].

REMARKS. Meunier [1895] proposed a new name Palaeoargyra as an extinct subgenus of Argyra without any included species, but later [Meunier, 1899] noted that he recognized the two different genera with fossil species, Palaeoargyra and Argyra. He did not mention the name Palaeoargyra in his "Monograph on Baltic amber Dolichopodidae", but noted [Meunier, 1908: 16] that one of his new Argyra species, A. mutabilis, deserved a new genus to be described later. The Palaeoargyra was never formally described, but was apparently proposed for $A$. mutabilis. Therefore, it was not necessary to coin a new species Palaeoargyra dytei (Evenhuis, 1994) with a bibliographic reference to a few obscure characters of no specific and generic importance given in Meunier [1895]. Regarding three more Argyra species described by Meunier [1907, 1908], they were all described by females with characters strongly contrasting with the generic concept of extant Argyra. E.g., A. debellata was described with parallel wing veins $\mathrm{R}_{4+5}$ and $\mathrm{M}_{1+2}$, A. debilis with shortened abdomen, and $A$. deceptoria with very short hind basitarsus and very large postpedicel of antenna. We consider these species names as doubtful names in Dolichopodidae until the type material will be studied. So, the diaphorine genus Argyra is here excluded from the Baltic amber fauna.

ACKNOWLEDGEMENTS. The authors are grateful to the staff members of the Laboratory of Arthropods, Paleontological Institute, Russian Academy of Sciences (Moscow), for their consultation and the material provided for this study. The work was supported by the Russian Foundation for Basic Research, grant No.14-04-00264-a.

\section{References}

Cumming J.M., Wood D.M. 2009. Adult morphology and terminology [Chapter] 2 // B.V. Brown, A. Borkent, J.M. Cumming, D.M. Wood, N.E. Woodley \& M.A. Zumbado (eds.). Manual of Central American Diptera. Vol.1. Ottawa: NRC Research Press. P.9-50. 
Evenhuis N.L. 1994. Catalogue of the fossil flies of the world (Insecta: Diptera). Leiden: Backuys Publ. P.I-VIII+1-600.

Grichanov I.Ya. 2010. A new genus of Medeterinae (Diptera: Dolichopodidae) from Baltic amber (Diptera) // Caucasian Entomological Bulletin. Vol.6. No.2. P.209-212.

Meunier F. 1895. Observations sur quelques diptères tertiaires et catalogue bibliographique complet sur les insectes fossiles de cet ordre // Annales de la Société Scientifique de Bruxelles (Mem.). Vol.19. P.1-17.

Meunier F. 1899. Revision des diptères fossiles types de Loew conservés au Musée Provincial de Koenigsberg // Miscellanea Entomologica: Revue entomologique internationale. Vol.7. P.161-165, 169-182.
Meunier F. 1907. Monographie des Dolichopodidae de l'ambre de la Baltique // Le Naturaliste. Ser.2. Vol.29. P.197-199, 209-211, 221-222, 233-235, 245-246, 260-262, 269-271, 281-282.

Meunier F. 1908a. Monographie des Dolichopodidae de l'ambre de la Baltique // Le Naturaliste. Ser.2. Vol.30. P.7-9, 21-23, 29$30,45-46,57-59$.

Meunier F. 1908b. Monographie des Dolichopodidae de l'ambre de la Baltique // Publications du Journal Le Naturaliste. P.1-100.

Yang D., Zhu Y., Wang M., Zhang L. 2006. World Catalog of Dolichopodidae (Insecta: Diptera). Beijing: China Agricultural University Press. P.1-704. 